\title{
Plant Growth-Promoting Rhizobacteria Enhance Onion (Allium cepa L.) Productivity and Minimize Requisite Chemical Fertilization
}

\author{
Aida H. Afify, F.I.A. Hauka and A.M. El-Sawah* \\ Microbiology Department, Faculty of Agriculture, Mansoura Univ., Mansoura, \\ Egypt.
}

\begin{abstract}
FIELD experiment was carried out on the farm of Faculty of Agriculture, Mansoura A University, Mansoura, Egypt during the winter season of 2016 to study the effect of bio-fertilization under different level of nitrogen and potassium $(75 \%$ and $50 \%$ from the full dose) on the growth and yield of Onion plants. The obtained results showed that the microbial inoculation leads to a significant increase in growth parameters (foliage heights, number of leaves and dry weights). As well as NPK-contents as responded to all treatments under investigation in all stages of plant growth. The same trend was observed in yield parameters (bulb weights, total bulbs yield, Total soluble solids\%, Dry matter\% and NPK contents in bulb tissues). The treatment T4 (A. chroococcum $+75 \%$ dose of NK) gave the highest total yield with an increase by $6.19 \%$ over the control. Also, the bio-fertilization has a pronounced increase in microbial count in comparison with the mineral fertilization. The obtained results of PGPR effects on growth parameters and yield of onion recommend their use as an alternative tool to reduce chemical fertilizers.
\end{abstract}

Keywords: Onion Allium cepa L., Azotobacter chroococcum, Klebsiella oxytoca and Rhizobium pusense.

\section{Introduction}

Onion (Allium cepa L.), a member of the family Amaryllidaceae, is a widely cultivated crop and second only to tomato in value among the vegetables (FAO 2005). In Egypt, it occupies an important position among vegetable crops not only for local consumption but also for exportation (Yaso et al. 2007). In recent years, the use of bio- fertilizers have considered a promising alternative for agricultural production and one of the best modern tools for providing nutrients to plants (Bhattacharjee and Dey 2014). Biofertilizers include a wide range of soil microbes, including the microbes, which fix nitrogen, solubilize phosphate, release potassium, produce phytohormones and promote plant growth. (Miransari 2011). These microbes can provide essential nutrients for plants mainly nitrogen, phosphorus and potassium and can improve the growth and yield of plants and reduce the use of chemical fertilizers (Bashan and de- Bashan 2005). Thus, in this study we focused on studying the effect of microbial inoculation with some PGPR strains individually and in mixture on the growth and the yield of onion plants which considered from the most economical crop in Egypt and on the microbial changes in the rhizosphere of onion plants.

\section{Materials and Methods}

Bacterial strains

Azotobacter chroococcum MF135558 ( $\mathrm{N}_{2}$ fixing bacteria, IAA producer), Klebsiella oxytoca MF135559 (P-solubilizing bacteria, IAA producer) and Rhizobium pusense MF135560 (K-releasing bacteria, IAA producer) were obtained from Agr. Microbiol. Dept., Fac. Agric., Mansoura Univ., Mansoura, Egypt.

\section{Preparation of inoculum}

The bacterial strains were grown to maximum growth at appropriate period of time up to $10^{8} \mathrm{cfu} / \mathrm{ml}$. Az. chroococcum MF135558 was grown in Modified Ashby's medium (Abd ElMalek and Ishac, 1968), K. oxytoca MF135559 in Pikovskaya's medium (Pikovskaya, 1948) and Rhizobium pusense MF135560 in modified Alexandroov's medium (Zahra, 1969). Equal volumes were mixed to make the mixtures of inoculum. Seedlings were soaked in microbial inoculants for $30 \mathrm{~min}$. Arabic gum (16\%) was used as an adhesive agent. An extra of $10 \mathrm{ml}$ culture was added to each plant (Khafagy, 2003).

*Corresponding author e-mail: ahmedelsawah89@mans.edu.eg

DOI: 10.21608/JENVBS.2019.6002.1036

(C)2017 National Information and Documentation Center (NIDOC) 


\section{Experimental design}

A field experiment was carried out on the farm of Faculty of Agriculture, Mansoura University, Egypt during the winter season of 2016 to study the effect of bio-fertilization on the growth and yield of Onion plants. Seedlings were transplanted at $1^{\text {st }}$ December 2016. The experiment was arranged as a completely randomized design with three replicates. Nitrogen fertilizer in the form of ammonium nitrate $(33.5 \% \mathrm{~N})$ at the rate of 45 and $67.5 \mathrm{Kg} \mathrm{N} /$ fed which represent 50 and $75 \%$ from the final recommended doses, was applied in two equal doses, before the first and second irrigations. Calcium super phosphate (12.5\% $\mathrm{P}_{2} \mathrm{O}_{5}$ ) at the rate of $150 \mathrm{~kg} /$ fed was applied during soil preparation. Potassium fertilizer in the form of potassium sulphate $\left(48 \% \mathrm{~K}_{2} \mathrm{O}\right)$ at the rate of 12 and $18 \mathrm{~kg} \mathrm{~K}_{2} \mathrm{O} /$ fed which represent 50 and $75 \%$ from the final recommended doses, was applied with the first dose of nitrogen fertilizer. The treatments were as follows:

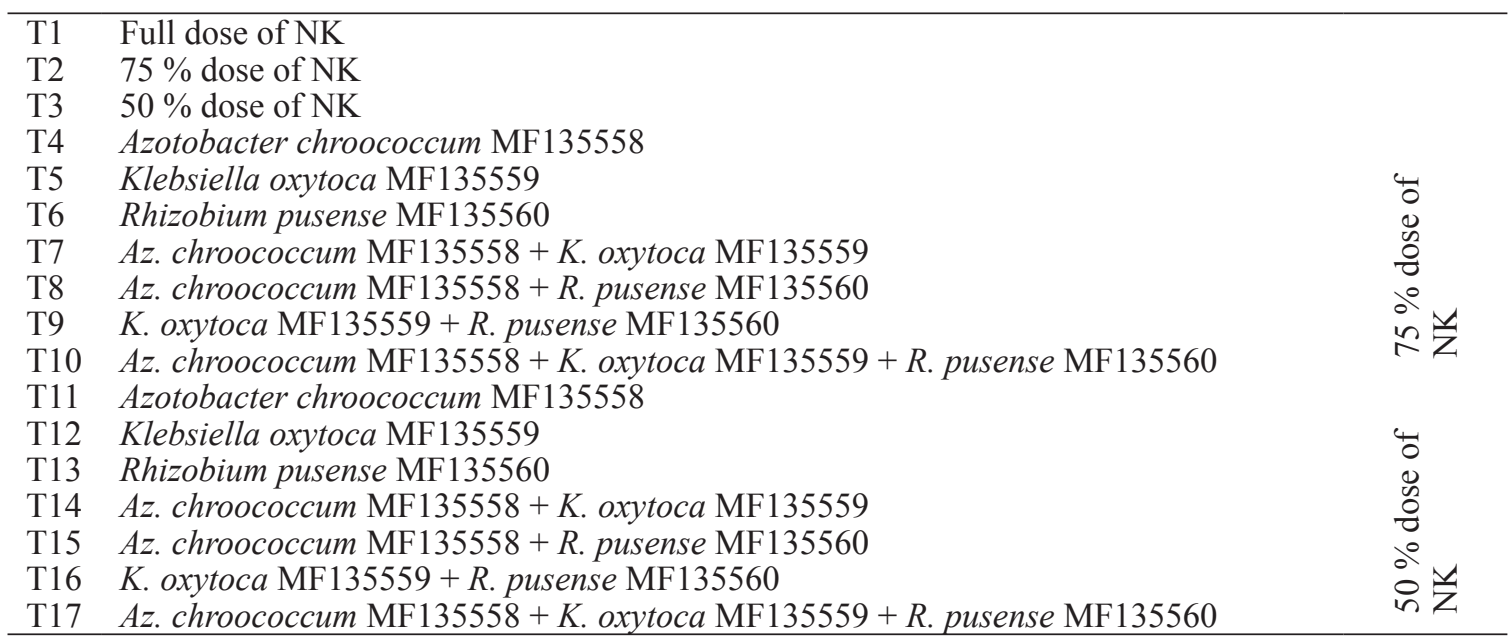

The physical, chemical and biological properties of the experimental soil were showed in Table 1.

\section{Plant sampling}

Samples were collected at 60, 90, 120 days after transplanting (DAT) and at the harvest stage.

TABLE 1. Initial physical, chemical and biological properties of the experimental soil.

\begin{tabular}{|c|c|}
\hline Properties & \\
\hline \multicolumn{2}{|l|}{ Texture analysis } \\
\hline Silt $(\%)$ & 53.70 \\
\hline Soil texture & Silty clay loam \\
\hline Organic matter (\%) & 1.14 \\
\hline $\mathrm{pH}$ soil-water suspension ratio $(1: 2.5)$ & 8.15 \\
\hline $\mathrm{Ca}^{++}$ & 7.45 \\
\hline $\mathrm{Mg}^{++}$ & 2.15 \\
\hline $\mathrm{Na}^{+}$ & 3.22 \\
\hline $\mathrm{K}^{+}$ & 0.20 \\
\hline \multicolumn{2}{|l|}{ Soluble anions $(\mathrm{meq} / \mathrm{L})$} \\
\hline $\mathrm{CO}_{3}^{--}$ & 0.00 \\
\hline Available P (ppm) & 7.58 \\
\hline Available K (ppm) & 156.0 \\
\hline \multicolumn{2}{|l|}{ Bacterial count } \\
\hline Total bacterial count & $1.43 \times 10^{6}$ \\
\hline Azotobacter spp. & $0.24 \times 10^{4}$ \\
\hline Phosphate dissolving bacteria & $5.80 \times 10^{4}$ \\
\hline Potassium releasing bacteria & $22.8 \times 10^{4}$ \\
\hline
\end{tabular}

Env. Biodiv. Soil Security Vol. 2 (2018) 


\section{Growth parameters}

Foliage height $(\mathrm{cm})$, Number of leaves/plant, Fresh weight (g/plant), Dry weight (g/plant), Crop growth Rate (CGR) at 60/90 and 90/120 DAT in $\mathrm{g}$ /day $(\mathrm{CGR}=\mathrm{W} 2-\mathrm{W} 1 / \mathrm{T} 2-\mathrm{T} 1$ where $\mathrm{W} 1$ and $\mathrm{W} 2$ refer to dry weights of plant at sampling time $\mathrm{T} 1, \mathrm{~T} 2$, respectively), Bulbing ratio at 120 DAT (It was counted as the ratio of the greatest diameter of bulb/the minimum neck diameter) and NPK content in plant.

\section{Yield parameters}

Bulb weight (g/plant), Total bulbs yield ( $\mathrm{t} /$ fed), Shape index (It was counted by dividing bulb height/bulb diameter), Total soluble solids percentage (TSS\%) by using a hand refract-meter, Bulb dry matter percentage (DM\%) and NPK content in bulb.

\section{Plant chemical analyses}

The finely powdered dry plant material was first digested with sulphoric-perchloric acids mixture. Total nitrogen content was determined calorimetrically at $420 \mathrm{~nm}$ by Nessler reagent (Lindner, 1944). Phosphorus content was determined calorimetrically at $660 \mathrm{~nm}$ by the method of Boltz and Mellon (1948) modified by Hemalatha et al., (2013). Potassium content was determined by atomic absorption spectroscopy (Jackson, 1973).

\section{Microbial count Determination \\ A) Total bacterial count}

Total bacterial count was counted on nutrient agar medium (Skerman, 1967) using pour-plate method. Colony counts were obtained after three days of incubation at 30C.

\section{B) Azotobacter count}

Azotobacter was counted on Ashby's medium (Abd-El-Malek and Ishac, 1968), using Most Probable Number (MPN) technique. Tubes were incubated at $30^{\circ} \mathrm{C}$ for $15-21$ days. At the end of incubation period the presence of characteristic surface Azotobacter pellicle was checked.

\section{C) Phosphate-solubilizing bacterial count}

Phosphate-dissolving bacteria was counted on Pikovskaya's medium (Pikovskaya's, 1948) by plate method. Clear zones around the colonies were recorded after 7 days incubation at $30^{\circ} \mathrm{C}$.

\section{D) Potassium-releasing bacterial count}

Potassium-dissolving bacteria was counted on modified Alexandroov medium (Zahra, 1969) by plate method. Plates were incubated at $30^{\circ} \mathrm{C}$ for 5 days.

\section{Statistical analysis}

The obtained experimental data were statistically analyzed using COSTAT (2005) software of analysis of variance (Gomez and Gomez, 1984). The means were compared using Duncan multiple range test at $\mathrm{p}=0.05$ as outlined by Snedecor and Cochran (1980).

\section{$\underline{\text { Results and Discussion }}$}

\section{Growth parameters}

The effect of chemical fertilization and microbial inoculation of onion plants on foliage heights $(\mathrm{cm})$, number of leaves per plant and dry weights $(\mathrm{g})$ per plant is presented in Table 2. Results revealed that the foliage heights, number of leaves and dry weights were significantly affected by the tested bio-fertilization treatments. The treatment T4 (Az. chroococcum $+75 \%$ dose of NK) was the best treatment in increasing the plant height $(94.33 \mathrm{~cm})$, followed by $\mathrm{T} 16$ (K. oxytoca $+R$. pusense $+50 \%$ dose of NK) which gave $(90.06 \mathrm{~cm})$ at 120 DAT. There was no significance between treatments number (T13, T12, T8, T9, T6 and T10) which gave values $(88.3,85.63,85.56,85.03,83.60$ and 83.60 $\mathrm{cm}$, respectively) and $\mathrm{T} 1$ (control, full dose of $\mathrm{NK}$ ) at 120 DAT. However, the highest number of leaves per plant at 120 DAT (12.66 leaves/ plant) was recorded with the treatment T4 ( $A z$. chroococcum $+75 \%$ dose of NK), followed by treatments number (T5, T15, T14 and T9) which gave values $(12.33,12.00,11.66$ and 11.33 leaves/ plant, respectively). While, the lowest number of leaves per plant were recorded with the treatments T10, T6 and T11, which gave values $(9.66,9.66$ and 8.66 leaves/plant, respectively). On the other hand, the treatment T4 (Az. chroococcum $+75 \%$ dose of NK) was the best treatment for enhancing dry weights of onion plants which gave value $36.33 \mathrm{~g} / \mathrm{plant}$ at $120 \mathrm{DAT}$, followed by the treatments number (T8, T9 and T13) which gave values $(34.25,32.03$ and 26.10) g/plant, respectively which were better than the value of T1 (control, full dose of NK). This increase is due to increasing the availability of nitrogen, phosphorus, potassium and trace elements and production of high quantity of auxins which play an important role in chlorophyll, enzymes, proteins synthesis, and promotion of protoplasm development and enhancing the translocation of assimilates. Same findings reported by Balemi et al., 2007; Kandil et al., 2011; Abo-Sedera et al., 2012; Fawzy et al., 2012; Ghodia, 2012 \&Salim and Abou El-Yazied, 2015.

Env. Biodiv. Soil Security Vol. 2 (2018) 
TABLE 2. Foliage heights, Number of leaves / plant and dry weights of onion plants at different crop growth stages as affected by bio-fertilization treatments.

\begin{tabular}{|c|c|c|c|c|c|c|c|c|c|}
\hline \multirow{3}{*}{ Treatments } & \multicolumn{3}{|c|}{ Plant height (cm) } & \multicolumn{3}{|c|}{ Number of leaves / plant } & \multicolumn{3}{|c|}{ Dry weight (g/plant) } \\
\hline & 60 & 90 & 120 & 60 & 90 & 120 & 60 & 90 & 120 \\
\hline & DAT & DAT & DAT & DAT & DAT & DAT & DAT & DAT & DAT \\
\hline T1 & $65.13^{\mathrm{a}^{*}}$ & $85.36^{\mathrm{a}}$ & $88.76^{\mathrm{bc}}$ & $5.66^{\mathrm{ab}^{*}}$ & $7.66^{\mathrm{a}-\mathrm{c}}$ & $10.00^{\mathrm{d}-\mathrm{g}}$ & $2.19^{\mathrm{bc}}$ & $8.92^{\mathrm{cd}}$ & $21.31^{\mathrm{f}}$ \\
\hline $\mathbf{T} 2$ & $52.56^{\mathrm{d}}$ & $77.06^{\mathrm{b}-\mathrm{d}}$ & $78.30^{\mathrm{ef}}$ & $5.00^{\mathrm{ab}}$ & $7.33^{\mathrm{a}-\mathrm{d}}$ & $9.33^{\mathrm{f}-\mathrm{h}}$ & $1.55^{\mathrm{ef}}$ & $6.55^{f}$ & $14.32^{\mathrm{j}}$ \\
\hline T3 & $47.56^{\mathrm{e}}$ & $68.73^{\mathrm{e}}$ & $74.36^{\mathrm{f}}$ & $4.66^{\mathrm{b}}$ & $6.00^{\mathrm{d}}$ & $8.33^{\mathrm{h}}$ & $1.04^{\mathrm{g}}$ & $5.43^{\mathrm{g}}$ & $12.35^{\mathrm{k}}$ \\
\hline T4 & $56.93^{\mathrm{cd}}$ & $77.16^{\mathrm{b}-\mathrm{d}}$ & $94.33^{\mathrm{a}}$ & $5.33^{\mathrm{ab}}$ & $7.00^{\mathrm{a}-\mathrm{d}}$ & $12.66^{\mathrm{a}}$ & $2.12^{\mathrm{bc}}$ & $11.29^{\mathrm{a}}$ & $36.33^{\mathrm{a}}$ \\
\hline T5 & $63.36^{\mathrm{a}}$ & $79.90^{\mathrm{a}-\mathrm{c}}$ & $82.10^{\text {de }}$ & $6.00^{\mathrm{a}}$ & $8.00^{\mathrm{ab}}$ & $12.33^{\mathrm{ab}}$ & $3.21^{\mathrm{a}}$ & $9.96^{\mathrm{b}}$ & $15.66^{\mathrm{i}}$ \\
\hline T6 & $53.60^{\mathrm{cd}}$ & $75.00^{\mathrm{b}-\mathrm{e}}$ & $83.60^{c-e}$ & $5.33^{\mathrm{ab}}$ & $7.33^{\mathrm{a}-\mathrm{d}}$ & $9.66^{\mathrm{e}-\mathrm{h}}$ & $1.97^{\mathrm{cd}}$ & $9.78^{\mathrm{b}}$ & $23.79^{\mathrm{e}}$ \\
\hline T7 & $56.10^{\mathrm{cd}}$ & $80.43^{\mathrm{a}-\mathrm{c}}$ & $81.76^{\mathrm{de}}$ & $6.00^{\mathrm{a}}$ & $8.00^{\mathrm{ab}}$ & $10.66^{b-f}$ & $1.67^{\mathrm{de}}$ & $9.61^{\mathrm{bc}}$ & $20.37^{\mathrm{fg}}$ \\
\hline T8 & $55.56^{\mathrm{cd}}$ & $81.53^{\mathrm{ab}}$ & $85.56^{\mathrm{b}-\mathrm{d}}$ & $5.66^{\mathrm{ab}}$ & $8.33^{\mathrm{a}}$ & $10.66^{\mathrm{b}-\mathrm{f}}$ & $2.42^{\mathrm{b}}$ & $11.21^{\mathrm{a}}$ & $34.25^{b}$ \\
\hline T9 & $63.40^{\mathrm{a}}$ & $83.73^{\mathrm{a}}$ & $85.03^{\mathrm{cd}}$ & $5.66^{\mathrm{ab}}$ & $7.00^{\mathrm{a}-\mathrm{d}}$ & $11.33^{\mathrm{a}-\mathrm{e}}$ & $3.14^{\mathrm{a}}$ & $10.18^{b}$ & $32.03^{c}$ \\
\hline T10 & $58.23^{\mathrm{bc}}$ & $80.00^{\mathrm{a}-\mathrm{c}}$ & $83.60^{\text {c-e }}$ & $6.00^{\mathrm{a}}$ & $8.00^{\mathrm{ab}}$ & $9.66^{\mathrm{e}-\mathrm{h}}$ & $2.25^{\mathrm{bc}}$ & $9.58^{\mathrm{bc}}$ & $17.05^{\mathrm{h}}$ \\
\hline T11 & $44.76^{\mathrm{e}}$ & $76.23^{\mathrm{b}-\mathrm{d}}$ & $80.20^{\text {de }}$ & $5.00^{\mathrm{ab}}$ & $6.33^{\mathrm{cd}}$ & $8.66^{\mathrm{gh}}$ & $1.16^{\mathrm{fg}}$ & $7.61^{\mathrm{e}}$ & $17.48^{\mathrm{h}}$ \\
\hline T12 & $54.50^{\mathrm{cd}}$ & $75.60^{\mathrm{b}-\mathrm{d}}$ & $85.63^{\mathrm{b}-\mathrm{d}}$ & $5.66^{\mathrm{ab}}$ & $6.66^{\mathrm{b}-\mathrm{d}}$ & $10.33^{\mathrm{c}-\mathrm{f}}$ & $2.04^{b-d}$ & $7.39^{\mathrm{e}}$ & $13.26^{\mathrm{jk}}$ \\
\hline T13 & $52.36^{\mathrm{d}}$ & $70.70^{\mathrm{de}}$ & $88.30^{\mathrm{bc}}$ & $5.33^{\mathrm{ab}}$ & $6.66^{\mathrm{b}-\mathrm{d}}$ & $10.66^{b-f}$ & $1.41^{\mathrm{e}-\mathrm{g}}$ & $7.46^{\mathrm{e}}$ & $26.10^{d}$ \\
\hline T14 & $53.03^{\mathrm{cd}}$ & $71.36^{\mathrm{de}}$ & $78.73^{\mathrm{ef}}$ & $5.33^{\mathrm{ab}}$ & $6.66^{\mathrm{b}-\mathrm{d}}$ & $11.66^{\mathrm{a}-\mathrm{d}}$ & $1.50^{\mathrm{ef}}$ & $8.78^{\mathrm{d}}$ & $20.27^{\mathrm{fg}}$ \\
\hline T15 & $54.83^{\mathrm{cd}}$ & $75.03^{\mathrm{b}-\mathrm{e}}$ & $78.83^{\mathrm{ef}}$ & $5.00^{\mathrm{ab}}$ & $8.00^{\mathrm{ab}}$ & $12.00^{\mathrm{a}-\mathrm{c}}$ & $1.34^{\mathrm{e}-\mathrm{g}}$ & $9.57^{\mathrm{bc}}$ & $19.55^{\mathrm{g}}$ \\
\hline T16 & $62.10^{\mathrm{ab}}$ & $74.40^{\mathrm{c}-\mathrm{e}}$ & $90.06^{\mathrm{ab}}$ & $5.66^{\mathrm{ab}}$ & $7.33^{\mathrm{a}-\mathrm{d}}$ & $10.66^{\mathrm{b}-\mathrm{f}}$ & $2.10^{\mathrm{bc}}$ & $9.51^{\mathrm{bc}}$ & $20.74^{\mathrm{fg}}$ \\
\hline T17 & $56.23^{\mathrm{cd}}$ & $73.20^{\text {de }}$ & $80.20^{\mathrm{de}}$ & $6.00^{\mathrm{a}}$ & $7.00^{\mathrm{a}-\mathrm{d}}$ & $10.33^{\mathrm{c}-\mathrm{f}}$ & $2.26^{\mathrm{bc}}$ & $9.74^{b}$ & $20.24^{\mathrm{fg}}$ \\
\hline
\end{tabular}

*Means followed by different letter(s) in the column are significantly different

Results listed in Table 3 revealed that the crop growth rate was significantly affected by the tested bio-fertilization treatments. The highest CGR values $(0.305$ and 0.834 at 60 to 90 and 90 to 120 DAT, respectively) were recorded by onion plants inoculated with T4 (Az. chroococcum +75 $\%$ dose of NK), followed by the treatment T8 ( $A z$. chroococcum $+R$. pusense $+75 \%$ dose of NK) which gave values $(0.292$ and 0.770 at 60 to 90 and 90 to 120 DAT, respectively). Same findings reported by Neeraja et al., 2000 and Kandil et al., 2011. Also, Results indicated that the bulbling ratio was not significantly affected by the tested mineral and bio-fertilization treatments. Same findings reported by Shaheen et al., 2007 and Kandil et al., 2011.

\section{NPK content in onion plants}

The effect of chemical fertilization and microbial inoculation application of onion plants on NPK content after 60, 90 and 120 DAT is presented in Table 4. Data shows that the $\mathrm{N}$-contents were significantly responded to all treatments under investigation. It was clear that the T4 (Az. chroococcum $+75 \%$ dose of NK) was the best treatment for enhancing $\mathrm{N}$-content in onion plants which gave values $(14.71,17.58$ and $20.03 \mathrm{mg} / \mathrm{g}$ dry weight after 60,90 and 120 DAT, respectively). Also, treatments number (T7,
T8 and T5) gave values (19.36, 19.30 and 18.82 $\mathrm{mg} / \mathrm{g}$ dry weight after 120 DAT, respectively) which were better than the value of T1 (control, full dose of NK). There was no significance between treatments number (T9, T14, T10, T15 and T6) which gave values $(18.23,18.06,18.02$, 18.00 and $18.00 \mathrm{mg} / \mathrm{g}$ dry weight after 120 DAT, respectively) and T1 (control, full dose of NK). However, the highest values in P-content (4.67, 4.57 and $4.46 \mathrm{mg} / \mathrm{g}$ dry weight after 120 DAT) were recorded by onion plants inoculated with T6, T9 and T4. Also, there was no significance between treatments number T8, T5, T16 and T11 which gave values $(4.423,4.346,4.330$ and 4.320 $\mathrm{mg} / \mathrm{g}$ dry weight after 120 DAT, respectively) and value of T1 (control). On the other hand, the highest values in K-content $(23.96,22.25$, $21.19,19.21$ and $18.86 \mathrm{mg} / \mathrm{g}$ dry weight after 120 DAT) were recorded by onion plants inoculated with T9, T4, T6, T7 and T13, respectively which were better than the value of T1 (control). The increase of nutrients content in plant can be due to the enhancement of the biological $\mathrm{N}_{2}$-fixation and/or production of organic acids to solubilize $\mathrm{P}$ and $\mathrm{K}$ and/or production of certain growth promoting substances, which positively affect root development and consequently their function in the uptake of both water and nutrients. The

Env. Biodiv. Soil Security Vol. 2 (2018) 
TABLE 3. Crop Growth Rate (CGR) and Bulbing ratio as affected by bio-fertilization treatments.

\begin{tabular}{cccc}
\hline \multirow{2}{*}{ Treatments } & \multicolumn{2}{c}{ CGR } & Bulbing ratio \\
\cline { 2 - 4 } T1 & $\mathbf{6 0} / \mathbf{9 0}$ DAT & $\mathbf{9 0 / 1 2 0 ~ D A T}$ & $1.78^{\mathrm{a}-\mathrm{d}}$ \\
T2 & $0.223^{\mathrm{f}-\mathrm{h}^{*}}$ & $0.412^{\mathrm{f}}$ & $1.67^{\mathrm{b}-\mathrm{d}}$ \\
T3 & $0.166^{\mathrm{jk}}$ & $0.258^{\mathrm{i}}$ & $1.49^{\mathrm{d}}$ \\
T4 & $0.146^{\mathrm{k}}$ & $0.230^{\mathrm{ij}}$ & $1.94^{\mathrm{a}-\mathrm{d}}$ \\
T5 & $0.305^{\mathrm{a}}$ & $0.834^{\mathrm{a}}$ & $1.70^{\mathrm{b}-\mathrm{d}}$ \\
T6 & $0.224^{\mathrm{f}-\mathrm{h}}$ & $0.190^{\mathrm{j}}$ & $2.07^{\mathrm{a}-\mathrm{c}}$ \\
T7 & $0.260^{\mathrm{c}-\mathrm{e}}$ & $0.466^{\mathrm{e}}$ & $2.21^{\mathrm{a}}$ \\
T8 & $0.264^{\mathrm{cd}}$ & $0.358^{\mathrm{gh}}$ & $1.94^{\mathrm{a}-\mathrm{d}}$ \\
T9 & $0.292^{\mathrm{ab}}$ & $0.770^{\mathrm{b}}$ & $1.86^{\mathrm{a}-\mathrm{d}}$ \\
T10 & $0.234^{\mathrm{d}-\mathrm{g}}$ & $0.727^{\mathrm{c}}$ & $1.83^{\mathrm{a}-\mathrm{d}}$ \\
T11 & $0.244^{\mathrm{c}-\mathrm{g}}$ & $0.248^{\mathrm{i}}$ & $1.98^{\mathrm{a}-\mathrm{c}}$ \\
T12 & $0.215^{\mathrm{gh}}$ & $0.329^{\mathrm{h}}$ & $1.76^{\mathrm{a}-\mathrm{d}}$ \\
T13 & $0.178^{\mathrm{ij}}$ & $0.195^{\mathrm{j}}$ & $1.84^{\mathrm{a}-\mathrm{d}}$ \\
T14 & $0.201^{\mathrm{hi}}$ & $0.621^{\mathrm{d}}$ & $1.64^{\mathrm{cd}}$ \\
T15 & $0.231^{\mathrm{e}-\mathrm{h}}$ & $0.394^{\mathrm{fg}}$ & $1.83^{\mathrm{a}-\mathrm{d}}$ \\
T16 & $0.274^{\mathrm{bc}}$ & $0.332^{\mathrm{h}}$ & $1.75^{\mathrm{a}-\mathrm{d}}$ \\
T17 & $0.246^{\mathrm{c}-\mathrm{f}}$ & $0.374^{\mathrm{f}-\mathrm{h}}$ & $2.10^{\mathrm{ab}}$ \\
\hline
\end{tabular}

*Means followed by different letter(s) in the column are significantly different

TABLE 4. NPK content ( $\mathrm{mg} / \mathrm{g}$ dry weight) of onion plants after 60, 90 and 120 days after transplanting (DAT) as affected by bio-fertilization treatments.

\begin{tabular}{|c|c|c|c|c|c|c|c|c|c|}
\hline \multirow[b]{2}{*}{ Treatments } & \multicolumn{3}{|c|}{$\mathrm{N}$-content in plant $(\mathrm{mg} / \mathrm{g})$} & \multicolumn{3}{|c|}{$P$-content in plant $(\mathrm{mg} / \mathrm{g})$} & \multicolumn{3}{|c|}{$\mathrm{K}$-content in plant $(\mathrm{mg} / \mathrm{g})$} \\
\hline & $\begin{array}{c}60 \\
\text { DAT }\end{array}$ & $\begin{array}{c}90 \\
\text { DAT }\end{array}$ & $\begin{array}{c}120 \\
\text { DAT }\end{array}$ & $\begin{array}{c}60 \\
\text { DAT } \\
\end{array}$ & $\begin{array}{c}90 \\
\text { DAT }\end{array}$ & $\begin{array}{c}120 \\
\text { DAT }\end{array}$ & $\begin{array}{c}60 \\
\text { DAT }\end{array}$ & $\begin{array}{c}90 \\
\text { DAT }\end{array}$ & $\begin{array}{c}120 \\
\text { DAT }\end{array}$ \\
\hline T1 & $13.30^{\mathrm{fg} *}$ & $14.68^{\mathrm{d}-\mathrm{f}}$ & $17.73^{\mathrm{d}-\mathrm{f}}$ & $1.646^{\mathrm{b}^{*}}$ & $2.546 \mathrm{~b}$ & $4.293^{\mathrm{de}}$ & $6.61^{\mathrm{b*}}$ & $14.20^{\mathrm{g}}$ & $17.84^{\mathrm{e}}$ \\
\hline $\mathbf{T 2}$ & $12.72^{\mathrm{gh}}$ & $13.94^{\mathrm{e}-\mathrm{g}}$ & $16.42^{\mathrm{gh}}$ & $1.313^{\mathrm{cd}}$ & $1.533^{\mathrm{g}-\mathrm{i}}$ & $4.163^{\text {ef }}$ & $4.65^{\mathrm{fg}}$ & $12.22^{\mathrm{j}}$ & $17.49^{\mathrm{ef}}$ \\
\hline T3 & $11.41^{\mathrm{i}}$ & $13.55^{\mathrm{g}}$ & $15.61^{\mathrm{h}}$ & $1.210^{\mathrm{d}}$ & $1.426^{\mathrm{i}}$ & $3.593^{\mathrm{i}}$ & $3.73^{\mathrm{ij}}$ & $9.93^{1}$ & $15.52^{\mathrm{i}}$ \\
\hline T4 & $14.71^{\mathrm{a}-\mathrm{c}}$ & $17.58^{\mathrm{a}}$ & $20.03^{\mathrm{a}}$ & $1.653^{\mathrm{b}}$ & $2.586^{\mathrm{b}}$ & $4.463^{\mathrm{bc}}$ & $5.03^{\mathrm{e}}$ & $19.00^{\mathrm{a}}$ & $22.25^{\mathrm{b}}$ \\
\hline T5 & $14.51^{\mathrm{a}-\mathrm{d}}$ & $14.72^{\mathrm{d}-\mathrm{f}}$ & $18.82^{\mathrm{bc}}$ & $2.136^{\mathrm{a}}$ & $3.553^{\mathrm{a}}$ & $4.346^{\mathrm{cd}}$ & $7.75^{\mathrm{a}}$ & $14.62^{\mathrm{f}}$ & $16.88^{\mathrm{gh}}$ \\
\hline T6 & $14.35^{\mathrm{b}-\mathrm{e}}$ & $14.91^{\mathrm{de}}$ & $18.00^{\mathrm{cee}}$ & $1.603^{\mathrm{b}}$ & $1.686^{\mathrm{eg} g}$ & $4.670^{\mathrm{a}}$ & $5.88^{\mathrm{c}}$ & $16.83^{\mathrm{b}}$ & $21.19^{\mathrm{c}}$ \\
\hline T7 & $13.55^{\mathrm{e}-\mathrm{g}}$ & $16.61^{b}$ & $19.36^{\mathrm{ab}}$ & $1.616^{\mathrm{b}}$ & $1.860^{\mathrm{e}}$ & $4.093^{\mathrm{fg}}$ & $4.14^{\mathrm{h}}$ & $16.73^{\mathrm{d}}$ & $19.21^{\mathrm{d}}$ \\
\hline T8 & $14.02^{\mathrm{c}-\mathrm{f}}$ & $16.20^{\mathrm{b}}$ & $19.30^{\mathrm{ab}}$ & $1.020^{\mathrm{e}}$ & $1.840^{\mathrm{e}}$ & $4.423^{\mathrm{cd}}$ & $5.38^{\mathrm{d}}$ & $17.17^{\mathrm{c}}$ & $17.71^{\mathrm{e}}$ \\
\hline T9 & $14.98^{\mathrm{ab}}$ & $16.32^{\mathrm{b}}$ & $18.23^{\mathrm{cd}}$ & $1.253^{\mathrm{d}}$ & $1.480^{\mathrm{hi}}$ & $4.576^{\mathrm{ab}}$ & $4.88^{\mathrm{ef}}$ & $15.33^{\mathrm{e}}$ & $23.96^{\mathrm{a}}$ \\
\hline T10 & $15.37^{\mathrm{a}}$ & $15.97^{\mathrm{bc}}$ & $18.02^{\mathrm{c}-\mathrm{e}}$ & $1.690^{\mathrm{b}}$ & $2.100^{\mathrm{d}}$ & $3.956^{\mathrm{gh}}$ & $6.00^{\mathrm{c}}$ & $14.54^{\mathrm{f}}$ & $17.68^{\mathrm{e}}$ \\
\hline T11 & $13.15^{\mathrm{f}-\mathrm{h}}$ & $15.21^{\mathrm{cd}}$ & $17.08^{\mathrm{e}-\mathrm{g}}$ & $1.323^{\mathrm{cd}}$ & $1.846^{\mathrm{e}}$ & $4.320^{\mathrm{c}-\mathrm{e}}$ & $3.75^{\mathrm{i}}$ & $11.90^{\mathrm{k}}$ & $16.52^{\mathrm{h}}$ \\
\hline T12 & $13.32^{\mathrm{fg}}$ & $14.80^{\mathrm{d}-\mathrm{f}}$ & $16.92^{\mathrm{fg}}$ & $1.210^{\mathrm{d}}$ & $2.306^{\mathrm{c}}$ & $4.166^{\mathrm{ef}}$ & $5.16^{\mathrm{de}}$ & $12.97^{\mathrm{i}}$ & $15.43^{\mathrm{i}}$ \\
\hline T13 & $13.64^{\mathrm{d}-\mathrm{g}}$ & $13.82 \mathrm{f}^{\mathrm{y}}$ & $16.43^{\mathrm{gh}}$ & $1.326^{\mathrm{cd}}$ & $1.403^{\mathrm{i}}$ & $4.160^{\mathrm{ef}}$ & $3.52^{\mathrm{i}-\mathrm{k}}$ & $14.13^{\mathrm{gh}}$ & $18.86^{\mathrm{d}}$ \\
\hline T14 & $12.74^{\mathrm{gh}}$ & $14.07^{\mathrm{e}-\mathrm{g}}$ & $18.06^{\mathrm{c}-\mathrm{e}}$ & $1.423^{\mathrm{c}}$ & $1.630^{\mathrm{f}-\mathrm{h}}$ & $3.873^{\mathrm{h}}$ & $3.32^{\mathrm{k}}$ & $16.46^{\mathrm{d}}$ & $17.15^{\mathrm{fg}}$ \\
\hline T15 & $13.40^{\mathrm{fg}}$ & $14.39 \mathrm{~d}^{-\mathrm{g}}$ & $18.00^{\mathrm{c}-\mathrm{e}}$ & $0.783^{\mathrm{g}}$ & $1.726^{\mathrm{e}-\mathrm{g}}$ & $3.933^{\mathrm{h}}$ & $3.81^{\mathrm{i}}$ & $13.95^{\mathrm{gh}}$ & $16.83^{\text {gh }}$ \\
\hline T16 & $12.31^{\mathrm{h}}$ & $14.63^{\mathrm{d}-\mathrm{f}}$ & $16.61^{\mathrm{gh}}$ & $1.240^{\mathrm{d}}$ & $1.333^{\mathrm{i}}$ & $4.330^{\mathrm{cd}}$ & $3.45^{\mathrm{jk}}$ & $11.69^{\mathrm{k}}$ & $15.84^{\mathrm{i}}$ \\
\hline T17 & $12.69^{\mathrm{gh}}$ & $14.58^{\mathrm{d}-\mathrm{f}}$ & $16.24^{\mathrm{gh}}$ & $0.893^{\mathrm{f}}$ & $1.740^{\text {ef }}$ & $3.903^{\mathrm{h}}$ & $4.44^{\mathrm{g}}$ & $13.86^{\mathrm{h}}$ & $16.56^{\mathrm{h}}$ \\
\hline
\end{tabular}

*Means followed by different letter(s) in the column are significantly different 
same findings were obtained by Salim and Abou El-Yazied (2015).

\section{Yield parameters}

Bulb weight

Averages bulb weight of onion plants as affected by chemical fertilization and bacterial inoculation are listed in Table 5. Results indicate that the mineral and bio-fertilization significantly affected bulb weight. The best treatment that enhancing bulb weights was $\mathrm{T} 4$, followed by $\mathrm{T} 8$ and T6 which gave values 298.91, 296.37 and $194.93 \mathrm{~g} / \mathrm{plant}$, respectively. The role of biofertilization in increasing the average of bulb weight may be attributed through increasing chlorophyll concentration and improving absorption of macro and micronutrients. Same findings reported by Kandil et al., 2011 when used 75\% NPK + biofertilizer (Soft Guard), Mahantheshet al. (2008) when used $125 \mathrm{~kg} \mathrm{~N}+$ $50 \mathrm{P}_{2} \mathrm{O}_{5}+125 \mathrm{~kg} \mathrm{~K} 2 \mathrm{O} /$ ha plus using Azospirillum as bio-fertilizer and Balemiet al. (2007) when used Azotobacter sp. CBD-15 and $75 \mathrm{Kg} \mathrm{N} \mathrm{ha}^{-1}$.

\section{Total bulbs yield}

Total bulbs yield ( $\mathrm{t} / \mathrm{fed}$ ) of onion plants as affected by chemical fertilization and bacterial inoculation are listed in Table 5. Results indicate that the mineral and bio-fertilization significantly affected total bulbs yield. At the same trend, the best treatment that enhancing total yield was T4, followed by T8 which gave values 19.976 and $19.645(\mathrm{t} / \mathrm{fed})$, respectively, with an increase by $6.19 \%$ and $4.43 \%$, respectively over the treatment T1 (control). This increase is due to the nutrients availability and production of high quantity of auxins in rhizosphere soil, which may increase the metabolic components synthesized in the plant and these in turn contribute much increase in the amount of metabolites translocated from different part of the plant to the bulb. Same findings reported by Balemiet al. (2007) when used Azotobacter sp. CBD-15 and $75 \mathrm{Kg} \mathrm{N} \mathrm{ha}^{-1}$, there is an increase of $13.5 \%$ marketable yield due to this treatment and Yaso et al. (2007) when used 60 $\mathrm{Kg} \mathrm{N} /$ fed with biofertilizer (Halex 2) containing N-fixing bacteria (Azospirillum, Azotobacter and klebsiella) gave the maximum marketable yield and total bulb yield.

\section{Bulb shape index}

Results listed in Table 5 indicated that shape index of onion bulbs did not significantly affect by the tested mineral and bio-fertilization treatments. This is due to the shape index of bulbs is a genetic character and can only change with onion variety. Same findings reported by Kandil et al., 2011.

\section{Total soluble solids (TSS\%)}

Results listed in Table 5 indicated that the best treatment that enhancing TSS\% was T4, followed by T8 and T9 which gave values $12.16 \%, 12.08 \%$ and $12.01 \%$. This increase is due to increasing the availability of minerals and consequently increasing their uptake which plays important role in the plant assimilation rate which in turn increased TSS\%. Results are in agreement with Balemi, 2005 who found an increase in $\mathrm{TSS} \%$ in onion tissues when used 75\% from recommended nitrogen per hectare with using Azotobacter bacteria as biofertilizer. Also, Singh et al., 2017 found that the treatment $(50 \% \mathrm{~N}+75 \% \mathrm{P}+\mathrm{K}+$ $50 \%$ Azotobacter $+25 \%$ PSB) enhanced the $\mathrm{TSS} \%$ in onion tissues to $12.28 \%$. Same findings also reported by Yaso et al., 2007; Abo-Sedera et al., 2012; Fawzy et al., 2012 and Ghodia, 2012.

\section{Bulb dry matter (DM\%)}

Results listed in Table 5 indicated that the best treatment that enhancing DM\% was T4, followed by T8, T11 and T17 which gave values $13.10 \%$, $13.01 \%, 12.08 \%$ and $12.00 \%$. This increase is due to the role of $\mathrm{N}$ in increasing $\mathrm{DM} \%$. Results are in agreement with Mohd-Mostakimet al., 2000 who found an increase in $\mathrm{DM} \%$ in onion tissues when used $130 \mathrm{~kg} \mathrm{~N}+80 \mathrm{~kg} \mathrm{~K} 2 \mathrm{O}+60 \mathrm{~kg} \mathrm{~K} \mathrm{O}_{2}$ /ha with using Azotobacter bacteria as bio-fertilizer. Same findings reported by Mahanthesh et al., 2008; Kandilet al., 2011 and Abo-Sedera et al., 2012.

\section{NPK content in onion bulb tissues}

Data in Table 5 show the effect of chemical fertilization and bacterial inoculation of onion plants on bulb $\mathrm{N}, \mathrm{P}$ and $\mathrm{K}$-content. $\mathrm{N}, \mathrm{P}$ and $\mathrm{K}$-contents were significantly responded to all treatments under investigation. The highest value in $\mathrm{N}$-content $(14.03,13.94,13.84 \mathrm{mg} / \mathrm{g}$ dry weight) was scored by onion plants inoculated with $\mathrm{T} 4$, T8 and T9, respectively with an increase $8.92 \%$, $8.22 \%$ and $7.45 \%$ over the control treatment. Also, treatments number (T10, T5, T6 and T7) gave high values $(13.36,13.31,13.06$, and $12.92 \mathrm{mg} / \mathrm{g}$ dry weight, respectively), there was no significance between these treatments and the value of T1 (control, full dose of NK). However, the highest values in P-content (3.990 mg/g dry weight) was scored by onion plants inoculated with $\mathrm{T} 5$ with an increase $34.97 \%$, followed by the treatments number (T4 and T10) which gave values (3.506 and $3.453 \mathrm{mg} / \mathrm{g}$ dry weight, respectively) with 
an increase $18.60 \%$ and $16.81 \%$, respectively, there was no significance between the treatments number (T7, T11, T12, T9, T6 and T8) which gave values $(3.08,3.07,3.06,3.03,3.01$ and $2.93 \mathrm{mg} / \mathrm{g}$ dry weight, respectively). On the other hand, the highest value in K-content $(14.61 \mathrm{mg} / \mathrm{g}$ dry weight) was scored by onion plants inoculated with (T10) with an increase 35.40 over the control followed by treatments number (T9, T5, T12, T4, T8, T6, T7 and T16) which gave high values $(14.29,13.98,13.03,12.58,12.34,11.61$, 11.37 and $11.30 \mathrm{mg} / \mathrm{g}$ dry weight, respectively) with an increase $38.43 \%, 29.56 \%, 20.75 \%$, $16.58 \%, 14.36 \%, 7.59 \%, 5.37 \%$ and $4.72 \%$, respectively) which were better than the value of T1 (control, full dose of NK). There was no significance between treatments T13 and T11 and the value of T1 (control, full dose of NK). This increase in nutrients content in bulb can be due to the enhancement of the nutrients availability and/or production of certain growth promoting substances, which may increase the metabolic components synthesized in the plant and these in turn contribute much increase in the amount of metabolites translocated from different part of the plant to the bulb. Results are in agreement with Balemi et al. (2007), Fawzy et al. (2012), Ghodia (2012) and Salim and Abou El-Yazied (2015). Bacterial counts

TABLE 5. Bulb weight (g), total bulbs yield (ton/fed), bulb shape index, total soluble solids (\%), bulb dry matter $(\%)$ and NPK content in bulb tissues of onion plants as affected by bio-fertilization treatments.

\begin{tabular}{|c|c|c|c|c|c|c|c|c|}
\hline \multirow{2}{*}{ Treatments } & \multirow{2}{*}{$\begin{array}{c}\text { Bulb } \\
\text { weight } \\
\text { (g) }\end{array}$} & \multirow{2}{*}{$\begin{array}{l}\text { Total } \\
\text { bulbs } \\
\text { yield }\end{array}$} & \multirow{2}{*}{$\begin{array}{l}\text { Bulb } \\
\text { shape } \\
\text { index }\end{array}$} & \multirow{2}{*}{ TSS\% } & \multirow{2}{*}{ DM\% } & \multicolumn{3}{|c|}{$\begin{array}{l}\text { NPK (mg/g dry weight) } \\
\text { in bulb tissues }\end{array}$} \\
\hline & & & & & & $\mathbf{N}$ & $\mathbf{P}$ & $\mathbf{K}$ \\
\hline T1 & $293.61^{\mathrm{a}^{*}}$ & $18.810^{\mathrm{bc}}$ & $0.810^{\mathrm{ab}}$ & $10.75^{\mathrm{b}-\mathrm{d}}$ & $11.89^{\circ}$ & $12.88^{\mathrm{b}-\mathrm{d}}$ & $2.956^{\mathrm{cd}}$ & $10.79^{\mathrm{h}}$ \\
\hline $\mathbf{T} 2$ & $265.21^{\text {cd }}$ & $15.312^{\mathrm{e}}$ & $0.792^{\mathrm{ab}}$ & $10.60^{\text {cd }}$ & $11.22^{\mathrm{c}-\mathrm{e}}$ & $12.28^{\mathrm{c}-\mathrm{f}}$ & $2.626^{\mathrm{e}}$ & $9.74^{\mathrm{i}}$ \\
\hline T3 & $219.71^{\mathrm{f}}$ & $10.904^{\mathrm{i}}$ & $0.754^{\mathrm{b}}$ & $10.16^{\mathrm{d}}$ & $9.24^{\mathrm{g}}$ & $11.97^{\text {ef }}$ & $1.910^{\mathrm{h}}$ & $8.15^{\mathrm{k}}$ \\
\hline T4 & $298.91^{\mathrm{a}}$ & $19.976^{\mathrm{a}}$ & $0.800^{\mathrm{ab}}$ & $12.16^{\mathrm{a}}$ & $13.10^{\mathrm{a}}$ & $14.03^{\mathrm{a}}$ & $3.506^{\mathrm{b}}$ & $12.58^{\mathrm{e}}$ \\
\hline T5 & $273.61^{\mathrm{bc}}$ & $17.936^{\mathrm{cd}}$ & $0.790^{\mathrm{ab}}$ & $11.44^{\mathrm{a}-\mathrm{c}}$ & $10.99^{\mathrm{c}-\mathrm{e}}$ & $13.31^{\mathrm{ab}}$ & $3.990^{\mathrm{a}}$ & $13.98^{\mathrm{c}}$ \\
\hline T6 & $294.93^{\mathrm{a}}$ & $17.565^{\mathrm{d}}$ & $0.804^{\mathrm{ab}}$ & $11.49^{\mathrm{a}-\mathrm{c}}$ & $11.18^{\mathrm{c}-\mathrm{e}}$ & $13.06^{\mathrm{bc}}$ & $3.013^{\mathrm{c}}$ & $11.61^{\mathrm{f}}$ \\
\hline $\mathbf{T} 7$ & $283.22^{\mathrm{bc}}$ & $17.488^{\mathrm{d}}$ & $0.808^{\mathrm{ab}}$ & $11.22^{\mathrm{a}-\mathrm{d}}$ & $11.41^{\mathrm{cd}}$ & $12.92^{\mathrm{b}-\mathrm{d}}$ & $3.083^{\mathrm{c}}$ & $11.37^{\mathrm{fg}}$ \\
\hline T8 & $296.37^{\mathrm{a}}$ & $19.645^{\mathrm{ab}}$ & $0.838^{\mathrm{ab}}$ & $12.08^{\mathrm{a}}$ & $13.01^{\mathrm{ab}}$ & $13.94^{\mathrm{a}}$ & $2.930^{\mathrm{cd}}$ & $12.34^{\mathrm{e}}$ \\
\hline T9 & $292.18^{\mathrm{a}}$ & $17.837^{\mathrm{d}}$ & $0.878^{\mathrm{a}}$ & $12.01^{\mathrm{a}}$ & $10.74^{\mathrm{d}-\mathrm{f}}$ & $13.84^{\mathrm{a}}$ & $3.036^{\mathrm{c}}$ & $14.29^{b}$ \\
\hline T10 & $287.73^{\mathrm{ab}}$ & $18.037^{\mathrm{cd}}$ & $0.858^{\mathrm{ab}}$ & $11.33^{\mathrm{a}-\mathrm{c}}$ & $10.17^{\mathrm{e}-\mathrm{g}}$ & $13.36^{\mathrm{ab}}$ & $3.453^{\mathrm{b}}$ & $14.61^{\mathrm{a}}$ \\
\hline T11 & $249.63^{\mathrm{e}}$ & $12.341^{\mathrm{h}}$ & $0.822^{\mathrm{ab}}$ & $10.74^{\mathrm{b}-\mathrm{d}}$ & $12.08^{b c}$ & $11.88^{\mathrm{e}}$ & $3.073^{\mathrm{c}}$ & $10.56^{\mathrm{h}}$ \\
\hline T12 & $246.21^{\mathrm{e}}$ & $14.192^{\mathrm{f}}$ & $0.804^{\mathrm{ab}}$ & $11.38^{\mathrm{a}-\mathrm{c}}$ & $10.96^{\mathrm{c}-\mathrm{e}}$ & $12.15^{\mathrm{d}-\mathrm{f}}$ & $3.060^{\mathrm{c}}$ & $13.03^{\mathrm{d}}$ \\
\hline T13 & $283.78^{\mathrm{ab}}$ & $15.186^{\mathrm{e}}$ & $0.862^{\mathrm{ab}}$ & $11.37^{\mathrm{a}-\mathrm{c}}$ & $10.98^{\mathrm{c}-\mathrm{e}}$ & $12.05^{\text {ef }}$ & $2.543^{\mathrm{ef}}$ & $10.83^{\mathrm{h}}$ \\
\hline T14 & $267.28^{\mathrm{cd}}$ & $14.101^{\mathrm{f}}$ & $0.810^{\mathrm{ab}}$ & $11.55^{\mathrm{a}-\mathrm{c}}$ & $11.39^{\mathrm{cd}}$ & $12.29^{\mathrm{c}-\mathrm{f}}$ & $2.606^{\mathrm{e}}$ & $9.85^{\mathrm{i}}$ \\
\hline T15 & $243.63^{\mathrm{e}}$ & $12.970^{\mathrm{gh}}$ & $0.834^{\mathrm{ab}}$ & $11.77^{\mathrm{ab}}$ & $11.47^{\mathrm{cd}}$ & $11.65^{\mathrm{f}}$ & $2.443 \mathrm{f}^{\mathrm{y}}$ & $9.70^{\mathrm{i}}$ \\
\hline T16 & $254.74^{\mathrm{de}}$ & $13.386^{\mathrm{fg}}$ & $0.848^{\mathrm{ab}}$ & $11.11^{\mathrm{a}-\mathrm{d}}$ & $9.74^{\mathrm{fg}}$ & $12.37^{\mathrm{c}-\mathrm{f}}$ & $2.830^{\mathrm{d}}$ & $11.30^{\mathrm{g}}$ \\
\hline T17 & $245.75^{\mathrm{e}}$ & $15.402^{\mathrm{e}}$ & $0.814^{\mathrm{ab}}$ & $11.50^{\mathrm{a}-\mathrm{c}}$ & $12.00^{\mathrm{bc}}$ & $12.45^{\mathrm{ce}}$ & $2.366^{\mathrm{g}}$ & $9.13^{\mathrm{j}}$ \\
\hline
\end{tabular}

*Means followed by different letter(s) in the column are significantly different

It's obvious from the results that the bacterial counts in the rhizosphere of inoculated treatments were higher than those in the rhizosphere of uninoculated ones. The bio-fertilization has a pronounced increase in bacterial count in comparison with the mineral fertilization. Also, it was observed that the highest values of bacterial numbers were obtained at 90 DAT under all applications, the counts were gradually increased until 90 DAT, however it decreased at 120 DAT, this is due to the decrease in roots exudates of old plants. In all stages of growth, by increasing $\mathrm{N}$-fertilizer, the bacterial count increased. Data in Table 6 show that the highest total bacterial count in onion rhizosphere being $241.56 \times 10^{6} \mathrm{cfu} / \mathrm{g}$ dry soil was recorded in the rhizosphere of onion plants inoculated with T4 (Az. chroococcum +75 $\%$ dose of NK), followed by (T6 and T 10) which gave also higher values $\left(238.84 \times 10^{6}\right.$ and 202.51 x $10^{6} \mathrm{cfu} / \mathrm{g}$ dry soil), respectively at 90 DAT. Also, data in Table 7 show that the inoculation with $A z$. chroococcum show an increase in Azotobacter 
spp. count where the treatment (T4 and T11) gave the highest values $\left(78.61 \times 10^{4}\right.$ and $59.76 \times 10^{4} / \mathrm{g}$ dry soil, respectively at 90 DAT), followed by T10 (Mixture $+75 \%$ dose of NK) which gave $58.42 \mathrm{x}$ $10^{4} / \mathrm{g}$ dry soil. However, data in Table 8 show that the treatment T8, T6, T7 and T9 gave the highest values (148.02, 147.11, 146.66 and $144.84 \mathrm{x}$ $10^{4} \mathrm{cfu} / \mathrm{g}$ dry soil, respectively at 90 DAT), also data in Table 9 show that the highest potassiumreleasing bacterial count being $305.13 \times 10^{4} \mathrm{cfu} / \mathrm{g}$ dry soil was recorded in the rhizosphere of onion plants inoculated with T8 (Az. chroococcum $+R$. pusense $+75 \%$ dose of NK), followed by T7 $(R$. pusense $+75 \%$ dose of NK) which gave value $255.18 \times 10^{4} \mathrm{cfu} /$ gram dry soil. Also, T9, T10 and T6 gave higher values $(248.83,245.19$ and $225.67 \times 10^{4} \mathrm{cfu} / \mathrm{g}$ dry soil), respectively at 90 DAT. The obtained results are in agreement with those obtained by Monib et al., 1982; Fayez et al., 1985; Zayed, 1999; Shahaby et al., 2000; Nain et al., 2000; Khafagy, 2003 and Hauka et al., 2010.

TABLE 6. Total bacterial count $\left(10^{6} \mathrm{cfu} / \mathrm{g}\right.$ dry soil) in the rhizosphere of onion plants after $30,60,90$ and 120 days after transplanting (DAT) as affected by bio-fertilization treatments.

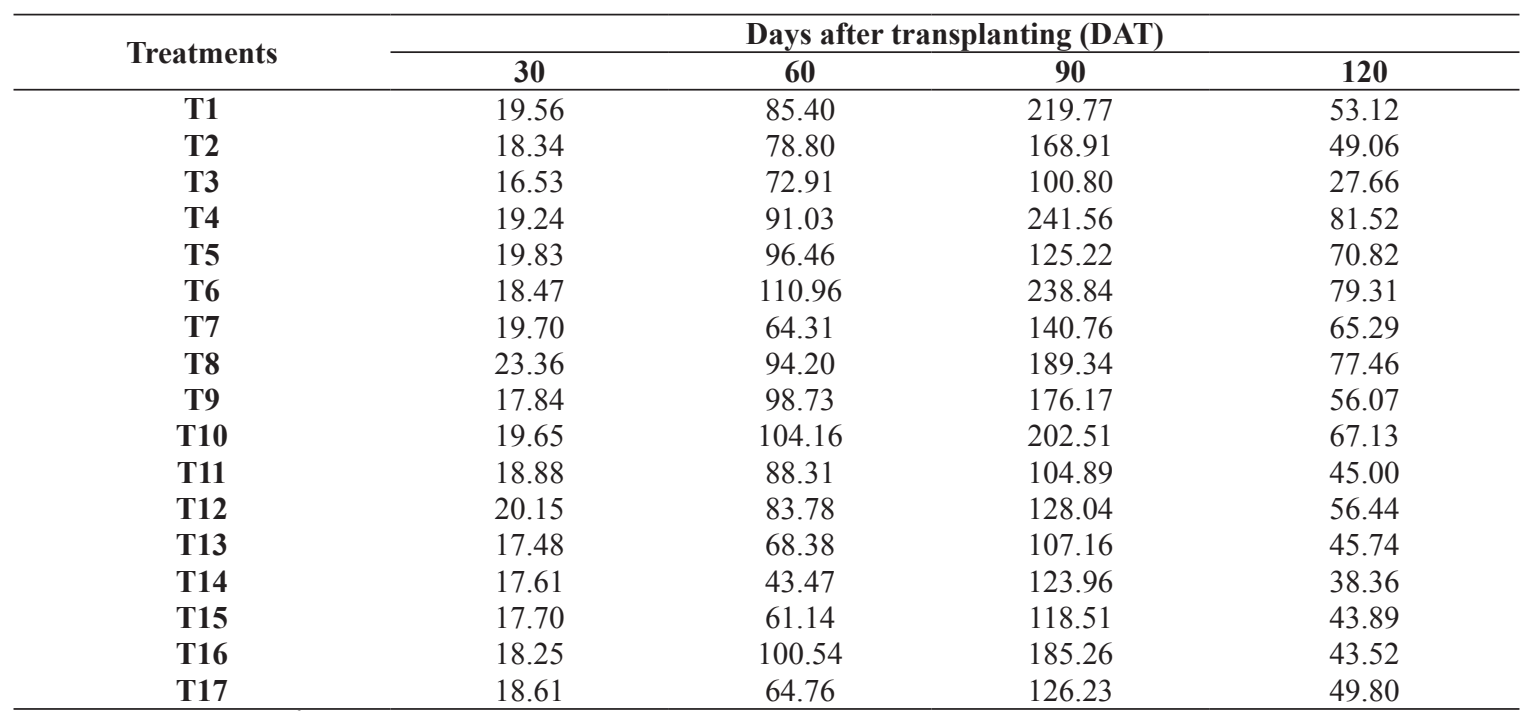

Initial count $1.43 \times 10^{6} \mathrm{cfu} / \mathrm{g}$ dry soil

TABLE 7. Counts of Azotobacter spp. $\left(10^{4} / \mathrm{g}\right.$ dry soil) in the rhizosphere of onion plants after $30,60,90$ and 120 days after transplanting (DAT) as affected by bio-fertilization treatments.

\begin{tabular}{|c|c|c|c|c|}
\hline \multirow{2}{*}{ Treatments } & \multicolumn{4}{|c|}{ Days after transplanting (DAT) } \\
\hline & 30 & 60 & 90 & 120 \\
\hline T1 & 1.49 & 2.62 & 4.63 & 1.54 \\
\hline $\mathbf{T} 2$ & 2.44 & 4.07 & 7.86 & 2.21 \\
\hline T3 & 2.30 & 3.65 & 6.26 & 2.17 \\
\hline T4 & 11.79 & 38.14 & 78.61 & 7.96 \\
\hline T5 & 6.25 & 7.08 & 40.76 & 4.98 \\
\hline T8 & 1.49 & 3.26 & 19.92 & 4.48 \\
\hline T9 & 1.63 & 5.01 & 28.53 & 2.21 \\
\hline T10 & 4.07 & 4.49 & 58.42 & 2.87 \\
\hline T11 & 3.78 & 12.94 & 59.76 & 7.74 \\
\hline T12 & 1.45 & 2.86 & 11.41 & 1.43 \\
\hline T16 & 1.04 & 1.63 & 12.90 & 1.01 \\
\hline T17 & 2.31 & 3.20 & 14.94 & 2.32 \\
\hline
\end{tabular}

Initial count $0.24 \times 10^{4} / \mathrm{g}$ dry soil

Env. Biodiv. Soil Security Vol. 2 (2018) 
TABLE 8. Phosphate solubilizing bacterial count $\left(10^{4} \mathrm{cfu} / \mathrm{g}\right.$ dry soil $)$ in the rhizosphere of onion plants after 30,60 , 90 and 120 days after transplanting (DAT) as affected by bio-fertilization treatments.

\begin{tabular}{ccccc}
\hline \multirow{2}{*}{ Treatments } & \multicolumn{4}{c}{ Days after transplanting (DAT) } \\
\cline { 2 - 5 } & $\mathbf{3 0}$ & $\mathbf{6 0}$ & $\mathbf{9 0}$ & $\mathbf{1 2 0}$ \\
\hline T1 & 47.10 & 80.55 & 98.07 & 59.39 \\
T2 & 45.28 & 70.65 & 79.00 & 42.79 \\
T3 & 38.49 & 45.28 & 68.11 & 38.36 \\
T4 & 46.19 & 89.22 & 130.31 & 83.00 \\
T5 & 62.50 & 98.27 & 139.39 & 56.80 \\
T6 & 48.00 & 112.77 & 147.11 & 50.53 \\
T7 & 46.64 & 85.14 & 146.66 & 46.11 \\
T8 & 56.61 & 115.03 & 148.02 & 49.80 \\
T9 & 50.72 & 117.75 & 144.84 & 44.26 \\
T10 & 57.51 & 106.88 & 114.42 & 47.58 \\
T11 & 35.32 & 43.93 & 138.49 & 57.17 \\
T12 & 43.47 & 53.89 & 122.14 & 46.48 \\
T13 & 54.34 & 76.99 & 115.33 & 41.68 \\
T14 & 46.19 & 57.51 & 119.42 & 43.16 \\
T15 & 43.02 & 61.59 & 132.58 & 44.26 \\
T16 & 43.93 & 71.10 & 118.05 & 45.00 \\
T17 & 30.79 & 82.88 & 102.16 & 56.80 \\
\hline
\end{tabular}

Initial count $5.80 \times 10^{4} \mathrm{cfu} / \mathrm{g}$ dry soil

TABLE 9. Potassium releasing bacterial count $\left(10^{4} \mathrm{cfu} / \mathrm{g}\right.$ dry soil) in the rhizosphere of onion plants after 30,60 , 90 and 120 days after transplanting (DAT) as affected by bio-fertilization treatments.

\begin{tabular}{ccccc}
\hline \multirow{2}{*}{ Treatments } & \multicolumn{4}{c}{ Days after transplanting (DAT) } \\
\cline { 2 - 4 } T1 & $\mathbf{3 0}$ & $\mathbf{6 0}$ & $\mathbf{9 0}$ & $\mathbf{1 2 0}$ \\
T2 & 85.14 & 171.78 & 203.42 & 71.56 \\
T3 & 69.74 & 139.49 & 152.56 & 55.70 \\
T4 & 58.42 & 119.11 & 127.13 & 34.30 \\
T5 & 75.63 & 161.68 & 179.81 & 80.41 \\
T6 & 143.11 & 156.25 & 182.99 & 59.02 \\
T7 & 113.22 & 190.67 & 225.67 & 60.49 \\
T8 & 57.97 & 189.76 & 255.18 & 44.26 \\
T9 & 71.55 & 162.59 & 305.13 & 99.97 \\
T10 & 163.04 & 177.53 & 248.83 & 62.71 \\
T11 & 111.86 & 195.19 & 245.19 & 67.87 \\
T12 & 69.29 & 133.60 & 147.57 & 52.38 \\
T13 & 83.33 & 117.30 & 169.36 & 43.16 \\
T14 & 94.65 & 173.46 & 203.87 & 58.65 \\
T15 & 56.15 & 140.85 & 154.83 & 54.22 \\
T16 & 45.28 & 146.73 & 200.69 & 62.34 \\
T17 & 105.52 & 161.68 & 172.54 & 43.16 \\
\hline
\end{tabular}

Initial count $22.8 \times 10^{4} \mathrm{cfu} / \mathrm{g}$ dry soil 


\section{Conclusion}

From the current study, it could recommend the possibility of using the individual bacterial inoculum, which containing Azotobacter chroococcum MF135558 in the presence of $75 \%$ dose of NK for enhancing growth and yield of onion plants and minimize the request of chemical fertilizers

\section{References}

Abd-El-Malek, Y. and Y. Z. Ishac (1968). Evaluation of methods used in counting Azotobacter. J. Appl. Bact., 31: 267-275.

Abo-Sedera, F.A; M.M. Merghany; M.F. Janet and M. A. Sharawy (2012). Effect of Bio and Mineral Fertilizers on Vegetative Growth and Productivity of Spring. Onion Annals of Agric. Sci., Moshtohor 50(1): $51-58$.

Balemi, T. (2005). Effect of integrated use of Azotobacter and nitrogen fertilizer on yield and quality of onion (Allium cepa L). ActaAgron. Hungarica, 54(4): 499-505.

Balemi, T.; N. Pal and A. K. Saxena (2007). Response of onion (Allium cepa L.) to combined application of biological and chemical nitrogenous fertilizers. Acta Agriculturae Slovenica, 89(1): 107 - 114

Bashan, Y. and L. E. de-Bashan (2005). Plant GrowthPromoting.Encyclopedia. Soils Environ., 1: 103115.

Bhattacharjee, R. B. and U. Dey (2014). Biofertilizers, a way towards organic agriculture. Afr. J. Microbiol. Res., 8: 2332-2342.

Boltz,F.D. and G.M.Mellon(1948). Spectrophotometric determination of phosphorus as molybdophosphoric acid. Anal. Chem., 20: 749-751.

COSTAT (2005). CoHort Software. Version 6.311, Lighthouse Ave, Monterey, CA., USA.

FAO Statistics (2005) FAOSTAT data. http://faostat. fao.org/faostat/. Cited 2006.

Fawzy, Z. F.; M. M. Abou El-magd; Y. Li; Z. Ouyang and A. M. Hoda (2012). Influence of Foliar Application by EM "Effective Microorganisms", Amino Acids and Yeast on Growth, Yield and Quality of Two Cultivars of Onion Plants under Newly Reclaimed Soil. J. Agric. Sci., 4(11): 26-39.

Fayez, M.; N. F. Eman and H. E. Makboul (1985). The possible use of nitrogen fixing Azospirillum as biofertilizer for wheat plants. Egypt. Microbiol., 20

\footnotetext{
Env. Biodiv. Soil Security Vol. 2 (2018)
}

\section{(3): 199-206.}

Ghodia, R. H. A. (2012) Productivity improvement of onion (Allium cepa L.) under Siwa oasis conditions. J. Plant Production, Mansoura Univ., 3(12): $3037-$ 3049 .

Gomez, K.A. and A.A. Gomez (1984). Statistical Procedures for Agricultural Research. 2nd Edn., John Wiley and Sons Inc., New York, USA., pp: 95-109.

Hauka, F. I. A.; Samia M. M. Bayoumy; Aida H. Afify; Eman H. Ashour and M.A. El-Awady (2010). Effect of using compost, mineral nitrogen and biofertilizer on microbial population in the rhizosphere of wheat plants cultivated in sandy soil. J. Agric. Chem. Biotechn., Mansoura Univ., 6: 307- 314.

Hemalatha, N.; N. Raja; A. Jayachitra; A. Rajalakshmi and N. Valarmathi (2013). Isolation and characterization of phosphate solubilizing bacteria and analyzing their effect on Capsicum annum $\mathrm{L}$. Inter. J. Biol. Pharm. Res.,4: 159-167.

Jackson, M. L. (1973). "Soil Chemical Analysis". Prentice- Hall of India Private Limited, New Delhi, India.

Kandil, A.A.; A.N.E Attia; A.E. Sharief and A.A.A. Leilh (2011). Response of onion (Allium cepa L.) yield to water stress and mineral biofertilization. Acta Agronomica Hungarica. 59(4): 361-370.

Khafagy, H.A.E (2003). Role of biofertilizers and organic matter in the improvement of plant growth and soil fertility in some newly reclaimed soil. $P h$. D. Thesis, Fac. Agric., Microbial Dept., Mansoura Univ., Mansoura, Egypt.

Lindner, RC. (1944). Rapid analytical method for some of the more common inorganic constituents of plant tissues. Plant Physiol. 19: 76-89.

Mahanthesh, B.; M.R.P. Sajjan; V. Srinivasa; M. Harshavardhan and D. Thippesha (2008). Studies on the influence of bio-fertilizers with levels of NPK on the yield and processing qualities of onion (Allium cepa L.) cv. Bellary Red in rabi season under irrigated situation. Res. on Crops, 9(1): 98102.

Miransari, M. (2011). Soil microbes and plant fertilization. Appl. Microbiol. Biotechnol., 92: 875-885.

Mohd-Mostakim; M.F. Ahmad and D.B. Singh (2000). Effect of Azotobacter and spacing on onion yield. Appl. Biol. Res., 2(1/2): 35-37. 
Monib, M.; N.A. Hegazi; E. Eid and S.E. Shokr (1982). Yield increase of grain sorghum (Sorghum vulgare) after inoculation with nitrogen fixing Azospirilla. The First OPAU Inter/African Conference on Biofertilizers, Cairo (Egypt).

Nain, L.R.; S. Paul and O.P. Verma (2000). Solid state fermentation of sorghum straw with cellucolytic Tichodermaviride strains and its effect on wheat in conjucation with Azotobacter chrococcum strains. WS. Indian J. Microbiol., 40 (1): 57-60.

Neeraja, G.; K.M. Reddy; P.S. Sarma and V.P Rao (2000). Physiological analysis of growth and yield in onion (Allium cepaL.) as influenced by irrigation and nitrogen. Annals of Agric. Res., 21(2): 199-205.

Pikovskaya, R. I. (1948). Mobilization of phosphorus in soil in connection with vital activity of some microbial species. Mikrobiologiya, 17: 362-370.

Salim, B. B. M. and A. Abou El-Yazied (2015). Effect of Bio-NP Fertilizer and Different Doses of Mineral $\mathrm{N}$ and P Fertilizers on Growth, Yield Productivity and some Biochemical Constituents of Wheat, Faba bean and Onion Plants. Middle East J. Appl. Sci., 5(4): 965-974.

Shahaby, A. F.; M. Fayez; M. N. Omar and H. S. Shehata (2000).Integration of diazotrophs inoculation with organic and inorganic fertilization to improve wheat and maize productivity in sandy soils. Egypt. J. Agric. Res., 78(2): 499-519.

Shaheen, A.M.; Fatma, A. Rizk and S.M. Singer
(2007). Growing onion plants without chemical fertilization. Res. J. Agric. and Biol. Sci., 3(2): 95104.

Singh, M.K.; N. Srivastava and R. K. Singh (2017). Integrated effect of biofertilizers and inorganic fertilizers on growth, yield and quality of onion (Allium cepa L.). J. PharmacognPhytochem., 6(5): 1841-1844.

Skerman, V.B.D. (1967). A Guide to Identification of The Genera of Bacteria. $2^{\text {nd }}$ ed. The Williams \& Wilkins Co. Baltimore.

Snedecor, G. W. and W. G. Cochran (1980). "Statistical Methods" $7^{\text {th }}$ Ed., Iowa State Univ. Press, Amr., USA, pp. 255-269.

Yaso, I. A.; H. S. Abdel-razzak and M. A. Wahballah (2007). influence of biofertilizer and mineral nitrogen on onion growth, yield and quality under calcareous soil conditions. J. Agric. Env. Sci. Alex. Univ., Egypt., 6(1): 245-263.

Zahra, M. K. (1969). Studies on silicate bacteria. M. Sc. Thesis, Fac. Agric., Cairo Univ., Egypt.

Zayed, G. (1999). Evaluation of $\mathrm{N}_{2}$-fixation efficiency of Azotobacter in alginate encapsulated and free cell systems. Egyptian J. of Microbiol., 34(1): 4555.

(Received 3/11/2018; accepted 10/1/2019) 